\title{
Evaluasi Kualitas Pelayanan pada Industri Angkutan Umum: Studi Kasus Mikrotrans Jak Lingko
}

\author{
Noveesra Zahra, Imam Baihaqi, dan Dewie Saktia Ardiantono \\ Departemen Manajemen Bisnis, Institut Teknologi Sepuluh Nopember (ITS) \\ e-mail: ibaihaqi@mb.its.ac.id
}

\begin{abstract}
Abstrak - Kemacetan dan polusi merupakan masalah besar yang terjadi di DKI Jakarta. Untuk mengurangi fenomena kemacetan dan tingginya tingkat polusi tersebut, Pemerintah Provinsi DKI Jakarta Anies Baswedan melakukan program revitalisasi sistem transportasi terintegrasi bernama Jak Lingko untuk memberi kemudahan bagi pengguna jalan area Jakarta dan sekitarnya. Program revitalisasi ini berbentuk pembaruan rute, pembaruan pelayanan seperti sistem pengangkutan sesuai titik yang telah ditentukan dan penjadwalan yang timetable, pembaruan sistem pembayaran, dan peremajaan armada. Sebagai jasa pelayanan masyarakat, penting bagi PT Transportasi Jakarta untuk mengedepankan kualitas layanan sesuai dengan harapan konsumen. Penelitian ini bertujuan untuk meningkatkan kualitas layanan Mikrotrans Jak Lingko melalui persepsi dan harapan penumpangnya. Metode yang digunakan pada penelitian ini adalah kombinasi dari SERVQUAL, dan Analytic Hierarchy Process (AHP). Hasil dari penelitian ini menunjukkan bahwa Customer Satisfaction Index (CSI) Mikrotrans Jak Lingko masuk ke dalam kategori puas dengan nilai 79,40\%. Dari 22 atribut kualitas layanan, keseluruhan atribut menunjukkan angka kesenjangan antara persepsi dan harapan dengan nilai negatif, sehingga diperlukan peningkatan pada keseluruhan atribut.
\end{abstract}

Kata Kunci-Analytic Hierarchy Process, Angkutan Umum, Customer Satisfaction Index, Jak Lingko, Kualitas Layanan, SERVQUAL.

\section{PENDAHULUAN}

$\mathrm{K}$ EMACETAN dan buruknya tingkat polusi udara merupakan masalah besar yang tidak kunjung usai, bahkan terus meningkat di kota Jakarta, Indonesia. Hal ini bisa diperbaiki dengan memperbaiki salah satu akar permasalahan yaitu suplai transportasi umum yang kurang memadai. Untuk mengurangi fenomena ini, Pemerintah Provinsi DKI Jakarta Anies Baswedan menargetkan jumlah pengguna transportasi umum yang semula sebanyak $19 \%$ menjadi $30 \%$ dari total pengguna jalan [1]. Dalam rangka meningkatkan angka tersebut, Pemprov DKI Jakarta melakukan program revitalisasi sistem transportasi terintegrasi bernama Jak Lingko untuk memberi kemudahan bagi pengguna jalan area Jakarta dan telah resmi dioperasikan pada Oktober 2018. Armada Jak Lingko terbagi menjadi dua kategori yaitu BRT (Bus Rapid Transit) dengan ukuran besar dan non-BRT dengan ukuran bus sedang ke besar dan bus kecil atau disebut juga dengan mikrotrans. Pada penelitian ini, objek yang akan dibahas adalah armada kecil Jak Lingko atau mikrotrans, yang sebelumnya sepenuhnya dioperasikan oleh operator swasta.
Tabel 1. Dimensi SERVQUAL

\begin{tabular}{|c|c|}
\hline Dimensi & Definisi \\
\hline Tangibles & $\begin{array}{l}\text { Penampilan fisik fasilitas, kelengkapan, } \\
\text { personel, dan bahan komunikasi }\end{array}$ \\
\hline Reliability & $\begin{array}{l}\text { Kemampuan untuk melakukan pelayanan yang } \\
\text { dijanjikan, dapat diandalkan, dan akurat. }\end{array}$ \\
\hline Responsiveness & $\begin{array}{l}\text { Kesediaan untuk membantu konsumen dan } \\
\text { memberikan layanan yang cepat. }\end{array}$ \\
\hline Assurance & $\begin{array}{l}\text { Pengetahuan dan kesopanan karyawan dan } \\
\text { kemampuan mereka untuk menginspirasi } \\
\text { kepercayaan dan kepercayaan diri. }\end{array}$ \\
\hline Empathy & $\begin{array}{l}\text { Kepedulian, kemudahan akses, komunikasi } \\
\text { yang baik, pemahaman konsumen dan } \\
\text { perhatian khusus yang diberikan kepada } \\
\text { konsumen. }\end{array}$ \\
\hline
\end{tabular}

Menurut penelitian yang telah dilakukan, indeks kepuasan penumpang Bus Transjakarta mencapai $74 \%$ Analisis Tingkat [2], KRL Commuter Line mencapai 74,14\% [3], dan MRT jakarta yang baru satu bulan berjalan tehitung April 2019 mencapai 85,10\% [4]. Beberapa penelitian terdahulu terkait angkutan umum di Jakarta telah menunjukan bahwa kepuasan penumpang dalam menggunakan jasa tersebut terbilang baik. Tingginya indeks kepuasan konsumen ini kontradiktif dengan fakta bahwa masih rendahnya angka pengguna transportasi umum. Walaupun kepuasan penumpang atas fasilitas transportasi umum yang sudah ada termasuk tinggi, cakupan transportasi umum tersebut belum meluas. Mikrotrans Jak lingko merupakan jawaban dari permasalahan ini karena armada dengan skala kecil dengan jumlah armada yang besar ini mencakup area yang lebih luas yang sulit dijamah oleh armada besar. Namun masih barunya penerapan Jak Lingko ini menyebabkan masih belum banyaknya penelitian yang dilakukan, sehingga tingkat kepuasan penumpang belum diketahui. Padahal sebagai penyedia layanan untuk khalayak umum, suara dari penumpang sangatlah penting untuk keberlangsungan program Jak Lingko. Maka dari itu penelitian ini bermaksud untuk mengevaluasi kualitas pelayanan Jak Lingko dari perspektif penumpang.

Penelitian dilakukan menggunakan metode SERVQUAL untuk mengidentifikasi kesenjangan antara persepsi dan harapan penumpang serta AHP untuk membobotkan tingkat kepentingan atribut layanan sebagai urutan prioritas peningkatan kualitas layanan. 
Tabel 2.

Kriteria Tingkat Kepuasan

\begin{tabular}{cc}
\hline \hline Nilai CSI (\%) & Keterangan (CSI) \\
\hline $81 \%-100 \%$ & Sangat Puas \\
$66 \%-88 \%$ & Puas \\
$51 \%-65 \%$ & Cukup Puas \\
$35 \%-50 \%$ & Kurang Puas \\
$\leq 34 \%$ & Tidak Puas \\
\hline \hline
\end{tabular}

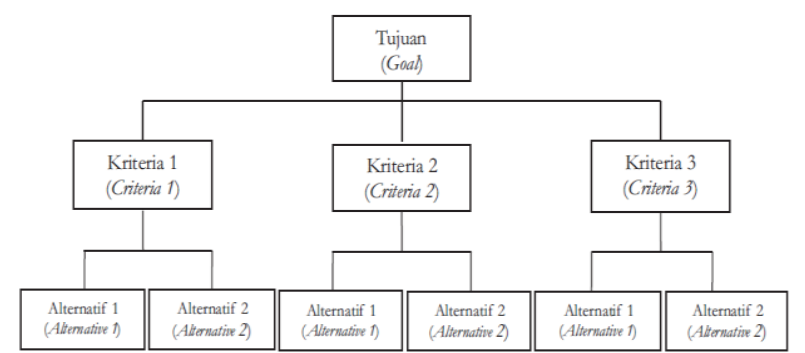

Gambar 1. Struktur Hierarki AHP

Sumber: Indartik, Djaenudin, \& Ginoga (2009) p. 86

Tabel 3.

Skala Numerik Kepentingan AHP

\begin{tabular}{|c|c|c|}
\hline $\begin{array}{c}\text { Intensitas } \\
\text { Kepentingan }\end{array}$ & Definisi & Penjelasan \\
\hline 1 & $\begin{array}{l}\text { Sama-sama } \\
\text { penting }\end{array}$ & $\begin{array}{l}\text { Dua elemen memiliki kepentingan } \\
\text { sama rata }\end{array}$ \\
\hline 3 & $\begin{array}{l}\text { Sedikit lebih } \\
\text { penting }\end{array}$ & $\begin{array}{l}\text { Satu elemen dianggap sedikit lebih } \\
\text { penting }\end{array}$ \\
\hline 5 & Lebih penting & $\begin{array}{l}\text { Satu elemen lebih penting } \\
\text { daripada yang lain }\end{array}$ \\
\hline 7 & $\begin{array}{l}\text { Sangat lebih } \\
\text { penting }\end{array}$ & $\begin{array}{l}\text { Satu elemen dominan daripada } \\
\text { yang lain }\end{array}$ \\
\hline 9 & $\begin{array}{l}\text { Mutlak lebih } \\
\text { penting }\end{array}$ & $\begin{array}{l}\text { Satu elemen jauh lebih penting } \\
\text { daripada yang lain }\end{array}$ \\
\hline $2,4,6,8$ & \multicolumn{2}{|c|}{$\begin{array}{l}\text { Nilai yang berdekatan, namun masih menunjukkan } \\
\text { kepentingan relatif dari elemen tersebut. }\end{array}$} \\
\hline
\end{tabular}

\section{II.LANDASAN TEORI}

\section{A. Mikrotrans Jak Lingko}

Mikrolet adalah angkutan kota skala kecil. Saat ini armada mikrolet di Jakarta ada yang dikelola sepenuhnya oleh operator swasta, dan ada yang dikelola oleh PT Transportasi Jakarta dibawah program Pemprov DKI Jakarta yang dinamakan Mikrotrans Jak Lingko. Adapun sistem pengelolaan mikrolet swasta masih konvensional dan Mikrotrans Jak Lingko memiliki skema pembayaran digital (tapping system) dan terintegrasi dengan moda angkutan umum lainnya.

\section{B. SERVQUAL}

Penelitian ini menggunakan metode SERVQUAL karena SERVQUAL dianggap dapat membantu berbagai organisasi layanan dalam menilai harapan dan persepsi konsumen atas kualitas suatu layanan [5]. Terdapat 5 dimensi (dapat dilihat pada Tabel 1) yang biasa disebut SERVQUAL yang digunakan konsumen dalam mengevaluasi kualitas sebuah pelayanan [6].

Kualitas layanan dapat diterjemahkan dari selisih antara kondisi eksisting yang dirasakan (persepsi) dan pelayanan ideal yang diinginkan penumpang (harapan). Selisih ini dapat disebut

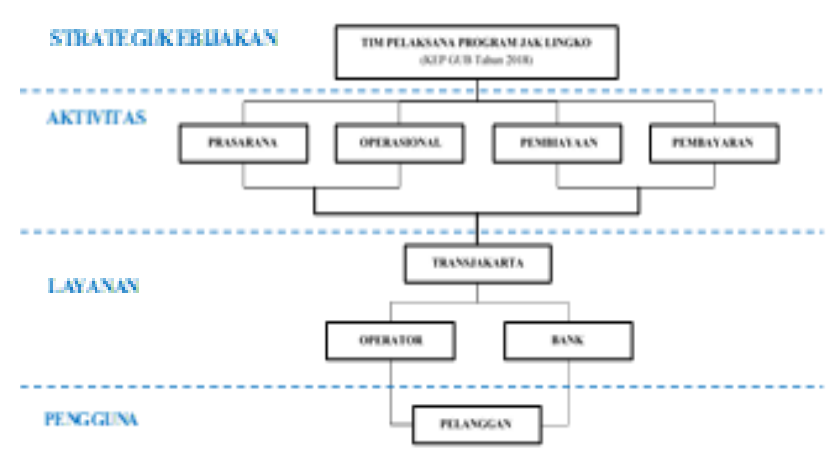

Gambar 2. Proses Bisnis Jak Lingko

Tabel 4.

Perubahan Sistem Setelah Bergabung dengan Jak Lingko

\begin{tabular}{|c|c|}
\hline $\begin{array}{c}\text { Sebelum Bergabung Program } \\
\text { Jak Lingko }\end{array}$ & $\begin{array}{c}\text { Setelah Bergabung Program } \\
\text { Jak Lingko }\end{array}$ \\
\hline $\begin{array}{l}\text { Banyak armada dioperasikan } \\
\text { oleh pengemudi ilegal (tidak } \\
\text { memiliki SIM) }\end{array}$ & $\begin{array}{l}\text { Armada memenuhi syarat untuk } \\
\text { beroperasi dengan pengemudi yang } \\
\text { legal (dengan SIM). }\end{array}$ \\
\hline $\begin{array}{l}\text { Penghasilan pengemudi hanya } \\
\text { berdasarkan jumlah } \\
\text { penumpang }\end{array}$ & $\begin{array}{l}\text { Pengemudi dibayar setiap bulan, } \\
\text { termasuk gaji pokok dan tunjangan }\end{array}$ \\
\hline $\begin{array}{l}\text { Menaik-turunkan penumpang } \\
\text { dilakukan dimana saja sesuai }\end{array}$ & $\begin{array}{lr}\text { Proses } & \text { menaik-turunkan } \\
\text { penumpang harus dilakukan di titik }\end{array}$ \\
\hline kehendak penumpang & $\begin{array}{l}\text { pemberhentian yang telah } \\
\text { ditentukan }\end{array}$ \\
\hline $\begin{array}{l}\text { Pembayaran tunai dengan nilai } \\
\text { yang tidak berstandar } \\
\text { (kehendak sopir) }\end{array}$ & $\begin{array}{l}\text { - Pembayaran tanpa uang tunai } \\
\text { menggunakan uang elektronik } \\
\text { (dengan kartu Jak Lingko). } \\
\text { - Nilai terstandarisasi; Saat ini, } \\
\text { hanya Rp0. }\end{array}$ \\
\hline
\end{tabular}

sebagai kesenjangan/gap yang dapat dikalkulasikan seperti berikut:

Keterangan:

$$
\text { Gap }=\text { Persepsi }- \text { Harapan }
$$

- Jika gap positif (persepsi > harapan), kualitas layanan dinyatakan sangat memuaskan

- Jika gap nol (persepsi = harapan), kualitas layanan dinyatakan memuaskan

- Jika gap negatif (persepsi < harapan), kualitas layanan dinyatakan tidak memuaskan

\section{Customer Satisfaction Index (CSI)}

CSI merupakan indeks guna menentukan tingkat kepuasan penumpang dengan pendekatan yang mempertimbangkan tingkat kepentingan dari berbagai atribut produk atau jasa yang diukur [7]. Customer Satisfaction Index (CSI) dapat dilihat pada Tabel 6.Kriteria tingkat kepuasan dapat dilihat pada Tabel 2.Untuk mengetahui indeks kepuasan, perhitungan dapat dilakukan sebagai berikut

Keterangan :

$$
\mathrm{CSI}=\frac{\mathrm{T}}{5 \mathrm{Y}} \times 100 \%
$$

$\mathrm{T}=$ Nilai total perkalian persepsi dan harapan

5 = Nilai maksimum skala pengukuran

$\mathrm{Y}=$ Nilai total kolom harapan 
Tabel 5 .

Atribut Layanan

\begin{tabular}{|c|c|c|c|}
\hline Dimensi & No & Atribut & Kode \\
\hline \multirow[t]{5}{*}{ Tangibility } & 1 & $\begin{array}{l}\text { Mikrotrans mudah diakses } \\
\text { semua kategori penumpang }\end{array}$ & $\mathrm{T} 1$ \\
\hline & 2 & Mikrotrans nyaman & $\mathrm{T} 2$ \\
\hline & 3 & $\begin{array}{l}\text { Fisik mikrotrans terlihat } \\
\text { bagus/indah }\end{array}$ & $\mathrm{T} 3$ \\
\hline & 4 & Kebersihan mikrotrans baik & $\mathrm{T} 4$ \\
\hline & 5 & Penampilan sopir rapi & $\mathrm{T} 5$ \\
\hline \multirow[t]{5}{*}{ Reliability } & 6 & \begin{tabular}{lrr} 
Mikrotrans & \multicolumn{2}{c}{ mengikuti } \\
jadwal yang & telah \\
ditetapkan & &
\end{tabular} & $\mathrm{R} 1$ \\
\hline & 7 & $\begin{array}{l}\text { Kesesuaian jalur dan rute } \\
\text { yang ditempuh }\end{array}$ & $\mathrm{R} 2$ \\
\hline & 8 & $\begin{array}{l}\text { Kesesuaian } \\
\text { pemberhentian }\end{array}$ & R3 \\
\hline & 9 & $\begin{array}{l}\text { Mikrotrans andal untuk } \\
\text { mengantar sampai tujuan }\end{array}$ & $\mathrm{R} 4$ \\
\hline & 10 & $\begin{array}{l}\text { Mesin tap pembayaran } \\
\text { mudah digunakan }\end{array}$ & R5 \\
\hline \multirow[t]{3}{*}{$\begin{array}{l}\text { Responsivene } \\
\text { ss }\end{array}$} & 11 & $\begin{array}{l}\text { Sopir tanggap dengan } \\
\text { permintaan penumpang }\end{array}$ & RP1 \\
\hline & 12 & $\begin{array}{l}\text { Sopir tanggap membantu } \\
\text { penumpang }\end{array}$ & RP2 \\
\hline & 13 & $\begin{array}{ll}\text { Perubahan pada } & \text { layanan } \\
\text { dikomunikasikan } & \text { terlebih } \\
\text { dahulu } & \end{array}$ & RP3 \\
\hline \multirow[t]{4}{*}{ Assurance } & 14 & $\begin{array}{l}\text { Penumpang merasa aman } \\
\text { terhadap barang bawaan }\end{array}$ & A1 \\
\hline & 15 & $\begin{array}{l}\text { Penumpang merasa aman } \\
\text { terhadap keselamatan diri }\end{array}$ & A2 \\
\hline & 16 & $\begin{array}{l}\text { Sopir andal dalam } \\
\text { mengemudi }\end{array}$ & A3 \\
\hline & 17 & Sopir sopan dan ramah & A4 \\
\hline \multirow[t]{5}{*}{ Empathy } & 18 & $\begin{array}{l}\text { Jadwal mikrotrans cocok } \\
\text { dengan aktivitas }\end{array}$ & E1 \\
\hline & 19 & $\begin{array}{l}\text { Sopir selalu bersedia } \\
\text { membantu penumpang }\end{array}$ & E2 \\
\hline & 20 & $\begin{array}{l}\text { Informasi mengenai operasi } \\
\text { mikrotrans mudah di akses }\end{array}$ & E3 \\
\hline & 21 & $\begin{array}{l}\text { Fasilitator penyedia kartu } \\
\text { Jak Lingko mudah di akses }\end{array}$ & $\mathrm{E} 4$ \\
\hline & 22 & $\begin{array}{lr}\text { Kemudahan } & \text { bagi } \\
\text { penumpang } & \text { untuk } \\
\text { menyampaikan } & \text { kritik dan } \\
\text { saran } & \end{array}$ & E5 \\
\hline
\end{tabular}

Berikut merupakan rekomendasi yang diusulkan Bhote (1996) dalam menentukan indeks kepuasan pelanggan:

\section{Analytic Hierarchy Process (AHP)}

Analytic Hierarchy Process (AHP) adalah metode yang telah dikembangkan oleh Thomas L. Saaty untuk yang digunakan untuk menentukan prioritas dan mendukung pengambilan keputusan yang kompleks. Struktur hierarki AHP dapat dilihat pada Gambar 1.Pada penelitian ini, penulis memilih untuk mebobotkan kepentingan dimensi dan atribut SERVQUAL bukan menggunakan expert judgement dari pengelola, namun menggunakan persepsi penumpang. Pada penelitian ini, AHP dapat mengidentifikasi urutan dimensi dari yang paling penting hingga yang kurang penting. Dalam membuat prioritas tersebut, berikut merupakan prosedur yang digunakan menurut Thomas L. Saaty. anatara lain; (1)Identifikasi masalah dan penentuan jenis informasi yang dicari; (2)Penyusunan hierarki. Struktur hierarki keputusan dari atas dengan tujuan keputusan,

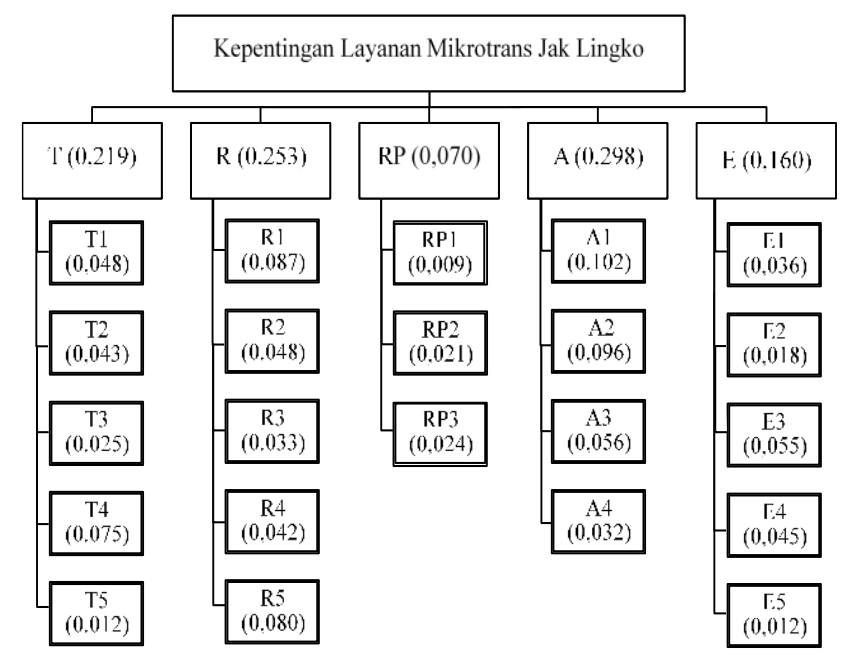

Gambar 3. Hierarki Kepentingan Atribut Layanan

Tabel 6.

Customer Satisfaction Index

\begin{tabular}{cccc}
\hline \hline Kode & Harapan $(\mathrm{I})$ & Persepsi $(\mathrm{P})$ & Skor $=(\mathrm{I}) \mathrm{x}(\mathrm{P})$ \\
\hline T1 & 4,63 & 4,15 & 19,21 \\
T2 & 4,53 & 4,02 & 18,24 \\
T3 & 4,37 & 4,00 & 17,47 \\
T4 & 4,53 & 4,06 & 18,38 \\
T5 & 4,18 & 3,82 & 15,97 \\
R1 & 4,44 & 3,36 & 14,90 \\
R2 & 4,56 & 4,31 & 19,66 \\
R3 & 4,41 & 4,03 & 17,78 \\
R4 & 4,53 & 4,10 & 18,59 \\
R5 & 4,54 & 4,32 & 19,62 \\
RP1 & 4,38 & 3,73 & 16,32 \\
RP2 & 4,46 & 4,24 & 18,89 \\
RP3 & 4,47 & 3,91 & 17,48 \\
A1 & 4,60 & 3,82 & 17,60 \\
A2 & 4,64 & 4,04 & 18,74 \\
A3 & 4,57 & 4,09 & 18,71 \\
A4 & 4,49 & 3,99 & 17,92 \\
E1 & 4,44 & 3,69 & 16,39 \\
E2 & 4,34 & 4,17 & 18,07 \\
E3 & 4,52 & 3,76 & 17,01 \\
E4 & 4,49 & 3,70 & 16,62 \\
E5 & 4,35 & 3,99 & 17,37 \\
\hline \hline
\end{tabular}

kemudian tujuan dari perspektif yang luas, melalui tingkat menengah (kriteria di mana elemen berikutnya tergantung) ke tingkat terendah (yang biasanya merupakan serangkaian alternatif) [9]; (3)Perbandingan elemen. Setiap elemen di tingkat atas digunakan untuk membandingkan elemen-elemen di tingkat bawah yang berhubungan [8]. Untuk membuat perbandingan, diperlukan skala angka yang menunjukkan kepentingan atau dominasi antar elemen yang dibandingkan. Berikut merupakan skala numerik untuk menentukan tingkat kepentingan dalam AHP dapat dilihat pada Tabel 3; (4)Penyusunan matriks. Penyusunan matriks berpasangan dilakukan untuk normalisasi bobot tingkat kepentingan pada tiap-tiap elemen pada hierarkinya masing-masing. Pada tahapan ini analisis dapat dilakukan secara manual ataupun dengan menggunakan program komputer seperti Expert Choice; (5)Uji konsistensi. Tingkat konsistensi menunjukkan suatu pendapat 
Tabel 7.

Gap Persepsi dan Harapan

\begin{tabular}{cccc}
\hline \hline Kode & Persepsi & Harapan & Gap \\
\hline T1 & 4,15 & 4,63 & $-0,49$ \\
T2 & 4,02 & 4,53 & $-0,51$ \\
T3 & 4,00 & 4,37 & $-0,37$ \\
T4 & 4,06 & 4,53 & $-0,47$ \\
T5 & 3,82 & 4,18 & $-0,37$ \\
R1 & 3,36 & 4,44 & $-1,08$ \\
R2 & 4,31 & 4,56 & $-0,24$ \\
R3 & 4,03 & 4,41 & $-0,38$ \\
R4 & 4,10 & 4,53 & $-0,44$ \\
R5 & 4,32 & 4,54 & $-0,22$ \\
RP1 & 3,73 & 4,38 & $-0,66$ \\
RP2 & 4,24 & 4,46 & $-0,22$ \\
RP3 & 3,91 & 4,47 & $-0,56$ \\
A1 & 3,82 & 4,60 & $-0,78$ \\
A2 & 4,04 & 4,64 & $-0,60$ \\
A3 & 4,09 & 4,57 & $-0,48$ \\
A4 & 3,99 & 4,49 & $-0,50$ \\
E1 & 3,69 & 4,44 & $-0,74$ \\
E2 & 4,17 & 4,34 & $-0,17$ \\
E3 & 3,76 & 4,52 & $-0,76$ \\
E4 & 3,70 & 4,49 & $-0,79$ \\
E5 & 3,99 & 4,35 & $-0,36$ \\
\hline \hline
\end{tabular}

mempunyai nilai yang sesuai dengan pengelompokan elemen pada hierarki serta menunjukan tingkat akurasi suatu pendapat terhadap elemen pada suatu tingkat hierarki.

\section{METODOLOGI PENELITIAN}

\section{A. Mempelajari karakterisik sistem Mikrotrans Jak Lingko}

Sistem mikrolet berbasiskan digital seperti Jak Lingko merupakan hal pertama di Indonesia. Penting untuk mempelajari karakteristik Mikrotrans Jak Lingko sebelum melakukan penelitian lebih jauh. Data proses bisnis ditunjukkan pada Gambar 2 dan tabel perubahan sistem ditunjukkan pada Tabel 4.

\section{B. Penentuan atribut SERVQUAL untuk perancangan kuesioner}

Berikut pada Tabel 5 merupakan atribut yang digunakan pada penelitian:

\section{C.Penyebaran Kuesioner}

\section{1) Kuesioner Tipe A}

Kuesioner ini disebar kepada masyarakat Jakarta dan sekitarnya yang telah menggunakan jasa Mikrotrans Jak Lingko lebih dari dua kali. Data dari kuesioner ini diolah dengan metode SERVQUAL dan CSI. Kuesioner ini dibagi menjadi tiga bagian seperti berikut: (a)Bagian I: Identifikasi karakteristik responden; (b)Bagian II: Identifikasi kepuasan responden sebagai penumpang sesuai pengalamannya dalam menggunakan jasa Jak Lingko; (c)Bagian III: Identifikasi pendapat responden selaku penumpang atas kepentingan atribut layanan Mikrotrans Jak Lingko.

\section{2) Kuesioner Tipe B}

Kuesioner ini disebar kepada penumpang yang telah menggunakan jasa Mikrotrans Jak Lingko sebanyak 10 kali
Tabel 8.

Bobot Kepentingan Atribut Layanan

\begin{tabular}{|c|c|c|c|c|}
\hline Dimensi & $\begin{array}{c}\text { Bobot } \\
\text { Dimensi }\end{array}$ & Atribut & $\begin{array}{l}\text { Bobot } \\
\text { Atribut }\end{array}$ & $\begin{array}{l}\text { Bobot } \\
\text { Global }\end{array}$ \\
\hline \multirow[t]{5}{*}{ Tangibility } & 0,219 & T1 & 0,239 & 0,048 \\
\hline & & $\mathrm{T} 2$ & 0,212 & 0,043 \\
\hline & & $\mathrm{T} 3$ & 0,122 & 0,025 \\
\hline & & $\mathrm{T} 4$ & 0,370 & 0,075 \\
\hline & & T5 & 0,057 & 0,012 \\
\hline \multirow[t]{5}{*}{ Reliability } & 0,253 & $\mathrm{R} 1$ & 0,299 & 0,087 \\
\hline & & $\mathrm{R} 2$ & 0,166 & 0,048 \\
\hline & & R3 & 0,115 & 0,033 \\
\hline & & R4 & 0,144 & 0,042 \\
\hline & & $\mathrm{R} 5$ & 0,276 & 0,080 \\
\hline \multirow[t]{3}{*}{ Responsiveness } & 0,070 & RP1 & 0,169 & 0,009 \\
\hline & & RP2 & 0,387 & 0,021 \\
\hline & & RP3 & 0,443 & 0,024 \\
\hline \multirow[t]{4}{*}{ Assurance } & 0,298 & A1 & 0,357 & 0,102 \\
\hline & & $\mathrm{A} 2$ & 0,337 & 0,096 \\
\hline & & A3 & 0,194 & 0,056 \\
\hline & & A4 & 0,111 & 0,032 \\
\hline \multirow[t]{5}{*}{ Empathy } & 0,160 & E1 & 0,216 & 0,036 \\
\hline & & $\mathrm{E} 2$ & 0,111 & 0,018 \\
\hline & & E3 & 0,331 & 0,055 \\
\hline & & E4 & 0,269 & 0,045 \\
\hline & & E5 & 0,073 & 0,012 \\
\hline
\end{tabular}

Synthesis with respect to:
\[ \begin{array}{l}\text { Goat: Kepentingan Atribut Mikrotrans Jak Lingko } \\ \text { Overall Inconsistency =.08 }\end{array} \]
Mudah diakses semua kategori penumpang

atau lebih. Kuesioner ini digunakan untuk mengdentifikasi bobot kepentingan atribut kualitas layanan.

\section{D.Populasi Responden Kuesioner}

\section{1) Responden Tipe A}

Masyarakat Jakarta dan sekitarnya yang berusia 18-65 tahun. Pernah melakukan perjalanan dengan Mikrotrans Jak Lingko sebanyak minimal 2 kali.

\section{2) Responden Tipe $B$}

Kelompok responden yang telah mengisi kuesioner tipe A.Pernah melakukan perjalanan dengan Mikrotrans Jak Lingko sebanyak minimal 10 kali.Responden tipe B merupakan responden terpilih sesuai kriteria dengan pengertian bahwa responden tipe B dianggap sebagai ahli dalam penelitian ini. 
Tabel 9.

Gap Terbobot

\begin{tabular}{cccc}
\hline \hline Kode & Gap & Bobot AHP & Gap terbobot \\
\hline T1 & $-0,49$ & 0,048 & $-0,024$ \\
T2 & $-0,51$ & 0,043 & $-0,022$ \\
T3 & $-0,37$ & 0,025 & $-0,009$ \\
T4 & $-0,47$ & 0,075 & $-0,035$ \\
T5 & $-0,37$ & 0,012 & $-0,004$ \\
R1 & $-1,08$ & 0,087 & $-0,094$ \\
R2 & $-0,24$ & 0,048 & $-0,012$ \\
R3 & $-0,38$ & 0,033 & $-0,013$ \\
R4 & $-0,44$ & 0,042 & $-0,018$ \\
R5 & $-0,22$ & 0,080 & $-0,018$ \\
RP1 & $-0,66$ & 0,009 & $-0,006$ \\
RP2 & $-0,22$ & 0,021 & $-0,005$ \\
RP3 & $-0,56$ & 0,024 & $-0,013$ \\
A1 & $-0,78$ & 0,102 & $-0,080$ \\
A2 & $-0,60$ & 0,096 & $-0,058$ \\
A3 & $-0,48$ & 0,056 & $-0,027$ \\
A4 & $-0,50$ & 0,032 & $-0,016$ \\
E1 & $-0,74$ & 0,036 & $-0,027$ \\
E2 & $-0,17$ & 0,018 & $-0,003$ \\
E3 & $-0,76$ & 0,055 & $-0,042$ \\
E4 & $-0,79$ & 0,045 & $-0,036$ \\
E5 & $-0,36$ & 0,012 & $-0,004$ \\
\hline \hline
\end{tabular}

\section{ANALISIS DAN PEMBAHASAN}

\section{A. Tingkat Kepuasan Penumpang}

Setelah hasil perhitungan jumlah skor tiap atribut, maka dimasukan ke dalam rumus berikut:

$$
C S I=\frac{390,93}{5 \times 98,47} \times 100 \%=79,40 \%
$$

Dari hasil perhitungan yang telah dilakukan, didapatkan bahwa indek kepuasan penumpang Mikrotrans Jak Lingko adalah sebesar $79,40 \%$.

\section{B. Kesenjangan Antara Persepsi dan Harapan Penumpang}

Data mengenai nilai persepsi dan harapan didapatkan dari penyebaran kuesioner tipe A. Berikut pada Tabel 7 merupakan perhitungan kesenjangan atau gap antara persepsi dan harapan penumpang atas kualitas atribut layanan.

\section{Bobot Kepentingan Atribut Layanan}

Pada tahap ini akan dijelaskan mengenai bobot dimensi berikut atributnya. Bobot pada dimensi dan atribut tersebut diambil berdasarkan hasil wawancara dengan responden tipe B. Pembobotan dilakukan dengan aplikasi expert choice. Berikut pada Tabel 8 merupakan hasil pembobotan kepentingan kualitas layanan pada Mikrotrans Jak Lingko dan pada Gambar 3 merupakan hierarki kepentingan atribut layanan berikut bobotnya dapat dilihat pada Tabel 5 .

Hasil pembobotan kepentingan atribut layanan dengan aplikasi expert choice pada Gambar 4 menunjukkan hasil pembobotan kepentingan atribut kualitas layanan secara keseluruhan. Pembobotan keseluruhan atribut tersebut menunjukkan nilai inconsistency dibawah 0,1 yaitu sebesar
Tabel 10.

Urutan Prioritas Peningkatan

\begin{tabular}{|c|c|c|}
\hline No & Atribut & Kode \\
\hline 1 & Mikrotrans mengikuti jadwal yang telah ditetapkan & $\mathrm{R} 1$ \\
\hline 2 & Penumpang merasa aman terhadap barang bawaan & A1 \\
\hline 3 & Penumpang merasa aman terhadap keselamatan diri & A2 \\
\hline 4 & $\begin{array}{l}\text { Informasi mengenai operasi mikrotrans mudah di } \\
\text { akses }\end{array}$ & E3 \\
\hline 5 & Fasilitator penyedia kartu Jak Lingko mudah di akses & E4 \\
\hline 6 & Kebersihan mikrotrans baik & $\mathrm{T} 4$ \\
\hline 7 & Sopir andal dalam mengemudi & A3 \\
\hline 8 & Jadwal mikrotrans cocok dengan aktivitas & E1 \\
\hline 9 & $\begin{array}{l}\text { Mikrotrans mudah di akses semua kategori } \\
\text { penumpang }\end{array}$ & $\mathrm{T} 1$ \\
\hline 10 & Mikrotrans nyaman & $\mathrm{T} 2$ \\
\hline 11 & Mikrotrans andal untuk mengantar sampai tujuan & $\mathrm{R} 4$ \\
\hline 12 & Mesin tap pembayaran mudah digunakan & R5 \\
\hline 13 & Sopir sopan dan ramah & A4 \\
\hline 14 & $\begin{array}{l}\text { Perubahan pada layanan dikomunikasikan terlebih } \\
\text { dahulu }\end{array}$ & RP3 \\
\hline 15 & Kesesuaian titik pemberhentian & $\mathrm{R} 3$ \\
\hline 16 & Kesesuaian jalur dan rute yang ditempuh & $\mathrm{R} 2$ \\
\hline 17 & Fisik mikrotrans terlihat bagus/indah & $\mathrm{T} 3$ \\
\hline 18 & Sopir tanggap dengan permintaan penumpang & RP1 \\
\hline 19 & Sopir tanggap membantu penumpang & RP2 \\
\hline 20 & Penampilan sopir rapi & T5 \\
\hline 21 & $\begin{array}{l}\text { Kemudahan bagi penumpang untuk menyampaikan } \\
\text { kritik dan saran }\end{array}$ & E5 \\
\hline 22 & Sopir selalu bersedia membantu penumpang & E2 \\
\hline
\end{tabular}

0,08 sehingga pembobotan seluruh atribut kualitas layanan dianggap valid dan layak dipergunakan.

\section{D.SERVQUAL Terbobot}

Nilai bobot AHP menunjukkan nilai kepentingan dari setiap atribut tersebut bagi penumpang Mikrotrans Jak Lingko. Sedangkan nilai gap menunjukkan nilai kesenjangan antara kenyataan yang dirasakan dan harapan yang bagi penumpang. Apabila nilai bobot tersebut dikalikan dengan nilai gap, akan menghasilkan nilai gap terbobot yang menunjukkan kepentingan dari atribut tersebut untuk dilakukan perbaikan. Gap terbobot dapat dilihat pada Tabel 9.

\section{E. Prioritas Peningkatan Kualitas Layanan}

Nilai perhitungan gap terbobot diurutkan, dengan nilai kesenjangan tertinggi yang dijadikan prioritas utama dalam peningkatan kualitas layanan. Berikut ada Tabel 10 merupakan uutan prioritas peningkatan.

\section{V.KESIMPULAN DAN SARAN}

Setelah dilakukan percobaan dan penelitian dari kedua kondisi pembebanan model maka kesimpulan dari Tugas Akhir ini adalah sebagai berikut: (1)Hasil analisis Customer Satisfaction Index (CSI) yang didasarkan oleh lima faktor yang telah ditentukan menunjukkan bahwa penumpang puas dengan 
kualitas Mikrotrans Jak Lingko. Hal ini ditunjukkan dengan angka kepuasan yang mencapai 79,40\%.; (2)Hasil pengolahan data SERVQUAL pada 22 atribut kualitas pelayanan, terdapat 22 atribut yang memiliki kesenjangan (gap) negatif antara persepsi dan harapan penumpang. Hal ini menunjukkan bahwa terdapat kekurangan dari seluruh aspek pelayanan Mikrotrans Jak Lingko. Adapun gap antara persepsi dan harapan terbesar ada pada atribut kesesuaian jadwal Mikrotrans Jak Lingko dengan yang telah ditetapkan dengan nilai kesenjagan sebesar 1,08. Sedangkan gap terkecil ada pada atribut kesediaan sopir untuk membantu penumpang dengan nilai kesenjangan sebesar -0,17; (3)Dari hasil pengolahan data dengan metode Analytical hierarchy Process (AHP), telah didapatkan bahwa faktor Assurance merupakan dimensi yang paling penting diantara dimensi yang lainnya dengan skor bobot sebesar 0,298. Adapun, atribut dengang bobot kepentingan tertinggi adalah keamanan terhadap barang bawaan penumpang (A1). Hal ini menunjukkan bahwa dimensi Assurance adalah dimensi kualitas layanan yang harus paling diperhatikan oleh PT Transportasi Jakarta untuk kebutuhan konsumennya.

Beberapa hal yang dapat disajikan sebagai saran pada penelitian ini adalah sebagai berikut: (1)Untuk penelitian lebih lanjut, disarankan untuk mengidentifikasi kendala dan faktor kesuksesan dalam implementasi SERVQUAL pada industri angkutan umum; (2)Atribut kualitas layanan yang telah dirancang pada penelitian ini dapat digunakan sebagai Voice of Customer; (3)Perlu dilakukan penelitian lebih lanjut terkait respon teknis yang dapat dilakukan PT Transportasi Jakarta untuk memenuhi kebutuhan penumpang. Dalam penerapannya, perlu analisis lebih jauh lagi tentang akar masalah utuk mendapatkan respon teknis yang tepat dan dapat diaplikasikan.

\section{DAFTAR PUSTAKA}

[1] CNN Indonesia, "Koreksi Jokowi, Anies Sebut Kerugian Macet Rp100 Triliun," CNN Indonesia, 09-Jan-2019. [Online]. Available: https://www.cnnindonesia.com/nasional/20190109180810-20359673/koreksi-jokowi-anies-sebut-kerugian-macet-rp100-triliun. [Accessed: 15-Jun-2020].

[2] A. M. Arifin, D. Gemina, and E. Silaningsih, "Analisis Tingkat Kepuasan Penumpang Pada Fasilitas Pelayanan Bus Transjakarta Berbasis Standar Pelayanan Minimal (SPM)," J. Sos. Hum., vol. 6, no. 2, pp. 104-121, 2015, doi: http://dx.doi.org/10.30997/jsh.v6i2.505.

[3] R. Triastoto, "Pengaruh Kualitas Pelayanan Publik Terhadap Tingkat Kepuasaan Masyarakat Pengguna Commuter Line Jabodetabek," Universitas Jenderal Soedirman, 2018.

[4] Berita IPB, "Riset Mahasiswa IPB; Tingkat Kepuasan Pengguna MRT Capai 85 Persen,” kumparan.com, 19-Jun-2019. [Online]. Available: https://kumparan.com/news-release-ipb/riset-mahasiswa-ipb-tingkatkepuasan-pengguna-mrt-capai-85-persen-1rUqBFz37Av. [Accessed: 15Jun-2020].

[5] Parasuraman, V. A. Zeithaml, and L. L. Berry, "SERVQUAL: a multipleitem scale for measuring consumer perceptions of service quality," $J$. Retail., vol. 64, no. 1, pp. 12-40, 1988, doi: 10.1016/S01482963(99)00084-3.

[6] A. P. and L. L. B. Zeithaml, V.A., Delivering costumer perceptions and expectations. New York: Free, 1990.

[7] K. R. Bhote, Beyond Customer Satisfaction to Customer Loyalty: The Key to Greater Profitability. American Management Association, 1996.

[8] T. L. Saaty, "Decision making with the analytic hierarchy process," Int. J. Serv. Sci., vol. 1, no. 1, pp. 83-98, 2008.

[9] W. Haller, E. Tiedeman, and R. Whitaker, "Expert choice-User Manual," Pittsburgh, PA Expert Choice, 1996. 